\title{
METABOLIC RESPONSES OF GUAVA TREES IRRIGATED WITH DIFFERENT N AND K LEVELS IN SÃO FRANCISCO VALLEY
}

\author{
BÁRBARA FRANÇA DANTAS ${ }^{2}$, MAIANE SANTOS PEREIRA ${ }^{3}$, LUCIANA DE SÁ RIBEIRO ${ }^{4}$, \\ JOSELANNE LUIZA TRAJANO MAIA ${ }^{5}$, DAVI JOSÉ SILVA ${ }^{6}$, LUIZA HELENA DUENHAS ${ }^{2}$, \\ MARIA AUXILIADORA COELHO DE LIMA ${ }^{2}$, LUIS HENRIQUE BASSOI ${ }^{2}$
}

\begin{abstract}
The guava (Psidium guajava L.) cv. Paluma has been cultivated in São Francisco Valley, Northeastern of Brazil, for in natura consumption and processing purposes. In spite of its importance, there are few scientific knowledge regarding guava physiology, nutrition, irrigation and fertigation. The objective of this work was to evaluate the effect of weather conditions and different concentrations of $\mathrm{N}$ and $\mathrm{K}$ applied by fertigation in foliar contents of reducing sugars, total soluble sugars, starch, sucrose, amino acids, and proteins. The field experiment was carried out at Bebedouro Experimental Field and the biochemical evaluations at the Laboratory of Seed and Plant Physiology, both located at Embrapa Semi-Árido, Petrolina-PE. The doses of $200 \mathrm{~g} \mathrm{~N}$ and $100 \mathrm{~g} \mathrm{~K}_{2} \mathrm{O} ; 400$ $\mathrm{g} \mathrm{N}$ and $200 \mathrm{~g} \mathrm{~K}_{2} \mathrm{O} ; 600 \mathrm{~g} \mathrm{~N}$ and $300 \mathrm{~g} \mathrm{~K}_{2} \mathrm{O}$; and $800 \mathrm{~g} \mathrm{~N}$ and $400 \mathrm{~g} \mathrm{~K}_{2} \mathrm{O}$ per plant were applied in an experiment field. The experimental design was totally randomized blocks, with four treatments and five blocks. The weather conditions influenced the plant photosynthesis, which affects the plants metabolism. Guava presented specific responses to $\mathrm{N}$ and $\mathrm{K}$ fertigation for each parameter evaluated. The weather conditions during the evaluation period influenced guava responses to $\mathrm{N}$ and $\mathrm{K}$ fertigation.
\end{abstract}

Index terms: Psidium guajava, primary metabolism, carbohydrate

\section{RESPOSTAS METABÓLICAS DE GOIABEIRAS IRRIGADAS COM DIFERENTES NÍVEIS DE N E K NO VALE DO SÃO FRANCISCO.}

\begin{abstract}
RESUMO -A goiabeira (Psidium guajava L.) cv. Paluma é cultivada no Vale do São Francisco, tanto para consumo in natura como para industrialização. Apesar da sua importância, existe pouco conhecimento científico em relação à fisiologia, nutrição mineral, irrigação e fertirrigação da goiabeira. O objetivo deste trabalho foi avaliar o efeito das condições meteorológicas e das diferentes doses de $\mathrm{N}$ e K, aplicados via fertirrigação, no teor foliar de açúcares redutores, açúcares solúveis totais, amido, sacarose, aminoácidos e proteínas totais. O experimento de campo foi desenvolvido no Campo Experimental Bebedouro e as análises bioquímicas no Laboratório de Sementes e Fisiologia Vegetal, ambos localizados na Embrapa Semi-Árido, Petrolina-PE. Foram utilizadas as doses de $200 \mathrm{~g} \mathrm{~N}$ e $100 \mathrm{~g} \mathrm{~K}_{2} \mathrm{O} ; 400 \mathrm{~g} \mathrm{~N}$ e $200 \mathrm{~g} \mathrm{~K} 2 \mathrm{O} ; 600 \mathrm{~g} \mathrm{~N} \mathrm{e} 300 \mathrm{~g} \mathrm{~K}_{2} \mathrm{O}$ e $800 \mathrm{~g} \mathrm{~N}$ e $400 \mathrm{~g} \mathrm{~K} 2 \mathrm{O}$ por planta. O experimento foi disposto em um delineamento em blocos ao acaso, com quatro tratamentos e cinco blocos. As condições meteorológicas influenciaram na fotossíntese das plantas, que, por sua vez, interferiu no metabolismo das mesmas. Para cada parâmetro avaliado, as goiabeiras apresentaram respostas específicas à fertirrigação com $\mathrm{N}$ e K. As condições meteorológicas durante os períodos avaliados influenciaram na resposta das goiabeiras à fertirrigação com $\mathrm{N}$ e K.
\end{abstract}

Termos para indexação: Psidium guajava, metabolismo primário, carboidratos.

\section{INTRODUCTION}

Among the several fruit species that have been cropped in São Francisco Valley, Northeastern Brazil, guava (Psidium guajava $L$.) stands out due to its importance for regional economy. The high productivity and high fruit quality of this species relies on many environmental factors, such as light, temperature, soil, $\mathrm{CO}_{2}$, water and nutrients. The combined action of these factors influences growth rates and sugar content in leaves and fruits, productivity, guaranteeing the fruits development and quality (Costa \& Costa, 2003).
In nitrogen $(\mathrm{N})$ and potassium $(\mathrm{K})$ deficiencies, guava trees develop intensified effects of $\mathrm{N}$ lack, which are sharp angles between branches and leaves, low vegetative vigor, chlorosis, erect trunk and roots with lighter colored than normal. Furthermore, guava trees present reduction in total leaf area, young leaves with reddish areas, which develop, to necrosis areas and at last to up roll of the leaves borders and chlorotic central area (Salvador et al., 1998).

Guava trees subjected to low light intensities present death of branches inside the shrub and low fruit production (Pereira, 1995). The photosynthesis rate of guava trees in

${ }^{1}$ (Paper 144-06). Received in 20-09-2006). Accepted for publication at 05-04-2007. Financial suport from FACEPE, CNPq.

${ }^{2}$ Resercher, Dr, Embrapa Semi-Árido, PO box 23, 56302-970, Petrolina - PE, barbara@cpatsa.embrapa.br, davi@cpatsa.embrapa.br, maclima@cpatsa.embrapa.br, lhbassoi@cpatsa.embrapa.br.

${ }^{3}$ Biologist, trainee, Embrapa Semi-Árido, Petrolina - PE, maybiosp@hotmail.com

${ }^{4}$ Biologist, Masters student in , UENF, Av. Alberto Lamego, 2000, 28013-600, Campos dos Goytacazes, Campos - RJ, lusrster@gmail.com

${ }^{5}$ Agronomist, M.Sc., CNPq scholarship, Embrapa Semi-Árido, Petrolina - PE.

${ }^{6}$ Analist in Science and Tecnology, Dr., CNPq, SEPN 509, Bloco A, Ed. Nazir I, Sala 301, 70750-501, Brasília - DF, Brazil, luizad@cnpq.br.

Rev. Bras. Frutic., Jaboticabal - SP, v. 29, n. 2, p. 323-328, Agosto 2007 
response to radiation levels is characteristic to $\mathrm{C}_{3}$ plants and the light saturation is high, with photosynthetic photons flux densities (PPFD) above to $925 \mathrm{mmol} . \mathrm{m}^{-1} \cdot \mathrm{s}^{-1}$ (Walker et al., 1979). High intensities of sun radiation induce higher levels of sugars and ascorbic acid in fruits (Rathore, 1976), while low intensities lead to low productivity (Pereira, 1995).

In spite of the importance of guava in São Francisco Valley, in literature there are few works regarding guava trees physiology, mineral nutrition, irrigation and fertigation. The objective of this work was to evaluate $\mathrm{N}$ and $\mathrm{K}$ doses applied by fertigation in sugars, proteins and amino acids in leaves of guava trees cv. Paluma.

\section{MATERIAL AND METHODS}

The field experiment was carried out at the Bebedouro Experimental Field and the biochemical evaluations at the Laboratory of Seed and Plant Physiology, both located at Embrapa Semi-Árido, Petrolina, Pernambuco State, Brazil (0909'S, $42^{\circ} 22^{\prime} \mathrm{W}$ ). Guava cv. Paluma seedlings were planted in May 2003 in a Yellow Red Oxisol, medium texture, in $6 \times 5 \mathrm{~m}$ grid spacing. Plants were irrigated by micro sprinklers, with fertilizer application through irrigation water.

The treatments were different doses of nitrogen $(\mathrm{N})$ and potassium (K) applied per plant: (1) $200 \mathrm{~g} \mathrm{~N}$ and $100 \mathrm{~g} \mathrm{~K}_{2} \mathrm{O}$; (2) $400 \mathrm{~g} \mathrm{~N}$ and $200 \mathrm{~g} \mathrm{~K}_{2} \mathrm{O}$; (3) $600 \mathrm{~g} \mathrm{~N}$ and $300 \mathrm{~g} \mathrm{~K}_{2} \mathrm{O}$; $800 \mathrm{~g} \mathrm{~N}$ and 400 $\mathrm{g} \mathrm{K}_{2} \mathrm{O}$. The experiment had a totally randomized blocks design, with four treatments and five blocks. During the trial the weather data were collected from an agro-meteorological station at the Bebedouro Experimental Field.

The third pair of leaves of fertile branches was sampled from guava trees for biochemical analysis, at a two weeks frequency, from Oct $26^{\text {th }} 2004$ to Feb $17^{\text {th }} 2005$ (57 to 171 days after pruning - DAP), during the first production cycle of the guava orchard. Leaves were grounded in distilled water (1:10, mass: volume) and centrifuged at $2500 \mathrm{xg}$. The supernatant, composed by soluble molecules, was collected for quantification of total soluble sugars (Moris, 1948; Yemm e Willis 1954), sucrose (Passos, 1996), reducing sugars (Miller, 1959), amino acids (Rosen, 1957) and proteins (Bradford, 1976). The precipitate was used for starch extraction (Allen et al., 1977) and quantification (Moris, 1948; Yemm e Willis 1954).

The weather data was collected from an agrometeorological station at the Bebedouro Experimental Field. The phenological phases of guava were observed and the partial and accumulated thermal sums of degree-days (DD) for each phase were calculated with maximum and minimum base temperatures (Tmax and Tmin, respectively) and base temperature (Tb) for the culture, which is $15^{\circ} \mathrm{C}$ (Bittenbender e Kobayashi, 2005). The formula for calculating DD was:

\section{$\mathrm{DD}=\Sigma[(\mathrm{Tmax}-\mathrm{Tmin}) / 2]-\mathrm{Tb}$.}

Harvest period has occurred from 141 to 200 DAP. The fruit weight $(\mathrm{g})$ and number per plant were recoded ad yield ( $\mathrm{t}$. $\mathrm{ha}^{-1}$ ) and average fruit weigh (g. fruit ${ }^{-1}$ ) were estimated.

\section{RESULTS AND DISCUSSION}

The blooming occurred at 49 DAP, 50\% flowering at 56 DAP, harvest begun at 141 DAP and the duration of the growing cycle of the irrigated guava cv. Paluma lasted 200 days (Table 1). These results agree with other authors verified that in general blooming begins around 50 DAP (Piza Junior \& Kavati, 1994), harvest begins from 135 to 150 DAP (Silva et al., 1994), the cycle duration lasts about 7 months (Piza Junior \& Kavati, 1994) and specifically for the Paluma cultivar the growing cycle lasted 200 days, between June and December 2001 in the São Francisco Valley (Ferreira, 2004).

With a $15^{\circ} \mathrm{C}$ base temperature the plants required 2306.7 DD from pruning to the end of harvest. Guava required 520.4 DD for bud bursting and initial vegetative growth (phase 1); 1107.2 DD for vegetative growth, blooming and physiological fruit drop (phase 2) and 1616.1 DD for fruit growth (phase 3). Guava trees cv. Paluma required more days and DD, 64 and 690.6, respectively, in the phase 4 (fruit maturation and harvest) (Table 1).

Increases of water-soluble proteins, reducing sugars, and total soluble sugars were observed in guava leaves in later phenological phases (Figure $1 \mathrm{~b}, \mathrm{c}$, and $\mathrm{d}$, respectively). On the other hand, amino acids (Figure 1a) and sucrose (Figure 1f) leaf content decreased until 85 DAP, increasing at the beginning of fruits growth, probably due to high sucrose translocation to fruits. The significant decrease at 112 DAP can be referred to low global solar radiation observed on the leaf sampling day (370.8 cal $\mathrm{cm}^{-2} \mathrm{~s}^{-1}$, Table 2). Starch content in leaves increased during initial fruit growth and initial fruit maturation (Figure 1e).

Phenological phases (PP), as well as weather conditions influence photosynthesis and photosynthesis transport rates, and thus the plants carbohydrate (CHO) and nitrogen $(\mathrm{N})$ metabolism (Taiz \& Zeiger, 1998). In guava leaves, proteins, reducing sugars and total soluble sugars were positively correlated to the number of DAP, PP and temperature and only total soluble sugars increased following radiation and insulation. Amino acids content was negatively correlated to plants phenology and positively correlated to weather conditions. Sucrose in guava leaves was not correlated to DAP and PP and presented low correlation to weather conditions. Except for leaf starch content, which had no correlation with any parameters evaluated, there was significant correlation among the macromolecules evaluated (Table 3 ).

Photosynthetic active tissues (sources), such as adult leaves, when exposed to saturating radiation, produce more $\mathrm{CHO}$ than required for its growth and metabolism, exporting exceeding photoassimilates (as sucrose) to photosynthetic inactive or less active tissues (sinks), such as young leaves, roots and developing fruits. During the photosynthesis, triose phosphate are produced and transported to the cytosol to synthesize fructose and glucose, which are reducing sugars. There are substrates for sucrose synthesis. On the other hand, when sink strength is little in relation to photosynthetic activity, there is an accumulation of triose phosphate in the leaf chloroplast inducing starch accumulation (Pimentel, 1998). Thus, there is a competition between sucrose and starch synthesis in source leaves during 
photosynthesis. This competition is confirmed by the results obtained in this work (Figure 1e, $\mathrm{f}$ ).

Regarding $\mathrm{N}$ and $\mathrm{K}$ treatments, the higher NK doses (800 $\mathrm{g} \mathrm{N} / 400 \mathrm{~g} \mathrm{~K}_{2} \mathrm{O}$ per plant) induced the highest amino acids leaves (Figure 1a), but the lowest water-soluble protein (Figure 1b) and reducing sugars (Figure 1c) content in Paluma guava leaves. The other carbohydrates did not respond to NK fertigation (Figure 1d, e, f). The guava leaves starch content presented a great increase during the physiological fruit drop and decreased during fruit growth, except for the $200 \mathrm{~g} \mathrm{~N} / 100 \mathrm{~g} \mathrm{~K}_{2} \mathrm{O}$ treated plants, and later at fruit maturation (Figure 1e).

According to Natale (1993), levels up to $900 \mathrm{~g}$ and 180 g.plant ${ }^{-1}$ of $\mathrm{N}$ and $\mathrm{K}_{2} \mathrm{O}$, respectively, induced higher yield (kg.ha$\left.{ }^{1}\right)$ and fruit average weight $(\mathrm{g})$, although fruit quality was not affected. High levels of $\mathrm{N}$ fertilization induce higher leaf contents of $\mathrm{N}, \mathrm{K}$ and $\mathrm{Mn}$, but lower leaf contents of Mg, P, S, Ca and high $\mathrm{K}$ levels induce lower $\mathrm{S}$ and $\mathrm{Mg}$ leaf content. In this experiment the higher NK levels leaded to higher production per tree, estimated yield and number of fruits (Figure 2a, b, c, respectively), but lower fruit weight (figure 2d). Although, in this experiment the higher NK doses induced higher yield, the metabolic responses to the nutrients were detected only for amino acids content in the leaves, which probably induced higher $\mathrm{N}$ turnover in the guava trees. During nitrogen turnover in plants, the conversion of inorganic $\mathrm{N}$ to organic $\mathrm{N}$ compounds of low molecular weight, such as amino acids, the synthesis of high molecular weight $\mathrm{N}$ compounds, such as proteins, nucleic acids and chlorophyll, and their breakdown by hydrolyzing enzymes are influenced by plant nutrition (Mengel \& Kirkby, 1987).

Peoples \& Koch (1979) have reported a clear effect of $\mathrm{K}^{+}$ the rate of $\mathrm{CO}_{2}$ assimilation, by promoting the synthesis of Ribulose-bisphosphate carboxylase and by decreasing diffusive resistance of $\mathrm{CO}_{2}$ in the mesophyll. Furthermore, $\mathrm{K}^{+}$has a promoting influence on phloem loading (Malek \& Baker, 1977) and on translocation of newly synthesized photosynthesis (Hartt, 1969) and of mobilized stored material (Koch \& Mengel, 1977; Seçer, 1978). The combined effect of high levels of $\mathrm{N}$ and $\mathrm{K}$ could have increased photosynthesis synthesis and transport leading t-o higher yields of guava trees.

TABLE 1 - Phenological phases of guava, cv Paluma, fertigated with different doses of N and K. Petrolina-PE.

\begin{tabular}{|c|c|c|c|c|c|c|c|}
\hline $\begin{array}{c}\text { Phenological } \\
\text { phase }\end{array}$ & Development events & Date & DAP & Development stages & $\begin{array}{l}\text { Number } \\
\text { of days }\end{array}$ & $\begin{array}{c}\text { Partial } \\
\text { DD }\end{array}$ & $\begin{array}{l}\text { Accumulated } \\
\text { DD }\end{array}$ \\
\hline \multirow{2}{*}{ P1 } & Pruning & $\begin{array}{l}\text { Aug } 30 \\
2004\end{array}$ & 0 & \multirow{2}{*}{$\begin{array}{l}\text { Bud burst and } \\
\text { vegetative growth }\end{array}$} & \multirow{2}{*}{48} & \multirow{2}{*}{520.4} & \multirow{2}{*}{520.4} \\
\hline & Bud burst & $\begin{array}{l}\text { Sep } 15 \\
2004\end{array}$ & 16 & & & & \\
\hline \multirow{5}{*}{$\mathrm{P} 2$} & Blooming & $\begin{array}{l}\text { Oct } 18 \\
2004\end{array}$ & 49 & \multirow{5}{*}{$\begin{array}{l}\text { Veg etative growth, } \\
\text { blooming and } \\
\text { physiological fruit } \\
\text { drop }\end{array}$} & \multirow{4}{*}{29} & \multirow{4}{*}{365.7} & \multirow{4}{*}{886.1} \\
\hline & $50 \%$ of flowering & $\begin{array}{l}\text { Oct } 25 \\
2004\end{array}$ & 56 & & & & \\
\hline & Beginning of fruit set & $\begin{array}{l}\text { Nov } 1 \\
2004\end{array}$ & 63 & & & & \\
\hline & $\begin{array}{c}\text { Beginning of } \\
\text { physiological fruits } \\
\text { drop }\end{array}$ & $\begin{array}{l}\text { Nov } 16 \\
2004\end{array}$ & 78 & & & & \\
\hline & $\begin{array}{l}\text { End of physiological } \\
\text { fruit drop }\end{array}$ & $\begin{array}{l}\text { Dec } 3 \\
2004\end{array}$ & 95 & & 32 & 221.05 & 1107.15 \\
\hline P3 & & & & Fruit growth & 41 & 508.95 & 1616.1 \\
\hline \multirow{3}{*}{$\mathrm{P} 4$} & $\begin{array}{l}\text { Beginning of fruit } \\
\text { maturation }\end{array}$ & $\begin{array}{c}\text { Jan } 13 \\
2005\end{array}$ & 136 & \multirow{3}{*}{$\begin{array}{c}\text { Fruit maturation and } \\
\text { harvest }\end{array}$} & \multirow{3}{*}{64} & \multirow{3}{*}{690.6} & \multirow{3}{*}{2306.7} \\
\hline & Beginning of harvest & $\begin{array}{c}\text { Jan } 18 \\
2005\end{array}$ & 141 & & & & \\
\hline & End of harvest & $\begin{array}{l}\text { Mar } 18 \\
2005\end{array}$ & 200 & & & & \\
\hline
\end{tabular}



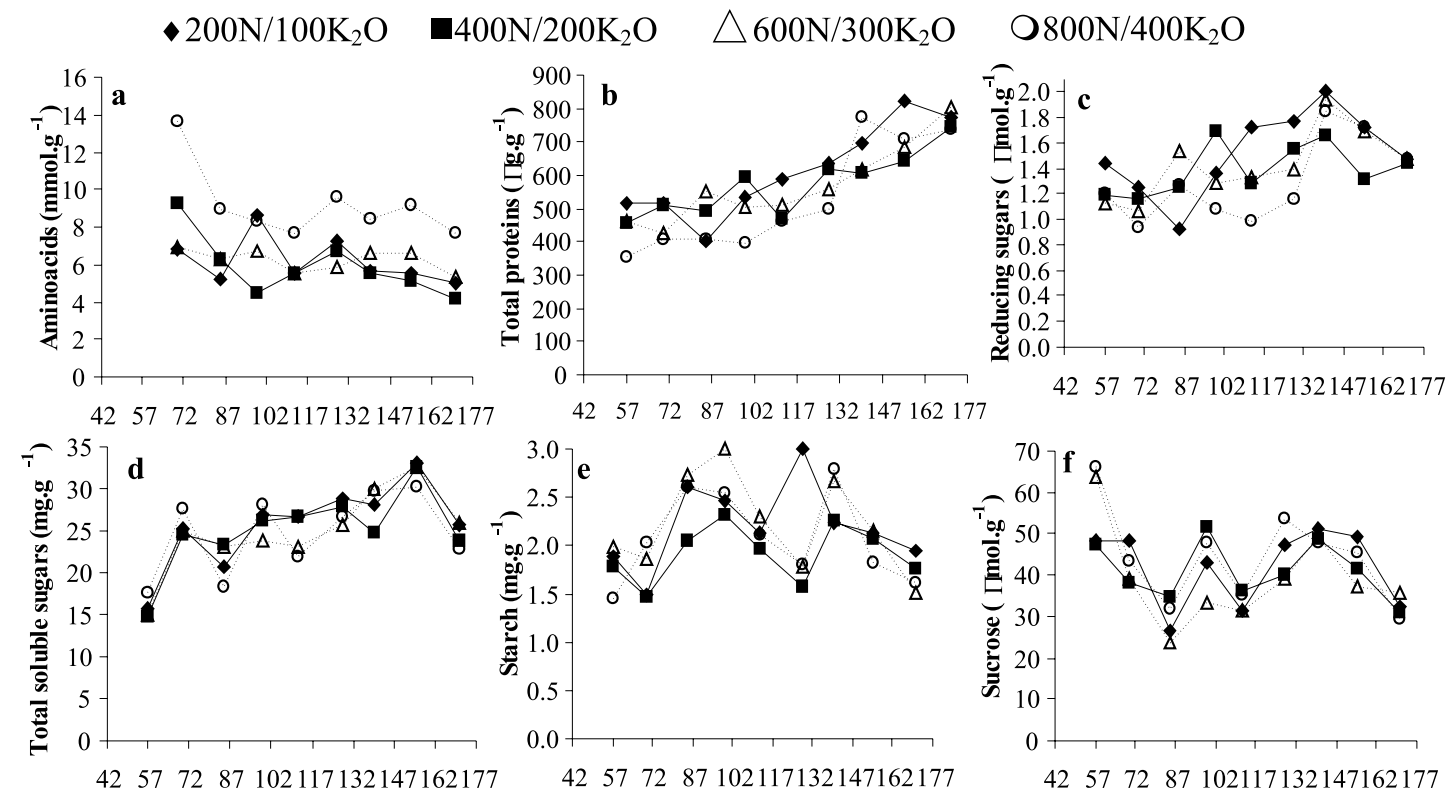

Days after pruning

FIGURE 1 - Contents of soluble aminoacids (a), water-soluble proteins (b), reducing sugars (c), total soluble sugars (d), starch (e) and sucrose (f) in guava leaves, fertigated with different doses (g. plant ${ }^{-1}$ ) of $\mathrm{N}$ and $\mathrm{K}_{2} \mathrm{O}$. Petrolina-PE.

TABLE 2 - Leaf sampling dates, number of days after pruning (DAP) and weather conditions. Petrolina-PE.

\begin{tabular}{|c|c|c|c|c|c|c|}
\hline Dates & DAP & $\begin{array}{c}\text { Average } \\
\text { temperature } \\
\left({ }^{\circ} \mathrm{C}\right)\end{array}$ & $\begin{array}{l}\text { Maximum } \\
\text { temperature } \\
\left({ }^{\circ} \mathrm{C}\right)\end{array}$ & $\begin{array}{l}\text { Minimum } \\
\text { temperature } \\
\left({ }^{\circ} \mathrm{C}\right)\end{array}$ & $\begin{array}{c}\text { Insolation } \\
\text { (hours) }\end{array}$ & $\begin{array}{l}\text { Global solar } \\
\text { radiation } \\
\left(\mathrm{cal} \mathrm{cm}^{-2} \mathrm{~s}^{-1}\right)\end{array}$ \\
\hline Oct 262004 & 57 & 28.5 & 36.5 & 20.2 & 9.6 & 440.6 \\
\hline Nov 82004 & 70 & 28.3 & 35.5 & 20.8 & 10.0 & 500.4 \\
\hline Nov 232004 & 85 & 24.4 & 30.0 & 20.0 & 1.6 & 316.3 \\
\hline Dec 72004 & 99 & 27.1 & 35.0 & 18.8 & 11.7 & 522.2 \\
\hline Dec 202004 & 112 & 28.1 & 35.5 & 20.4 & 9.1 & 370.8 \\
\hline Jan 52005 & 128 & 27.6 & 36.0 & 19.0 & 10.3 & 421.8 \\
\hline Jan 172005 & 140 & 26.1 & 33.0 & 19.0 & 6.4 & 352.1 \\
\hline Feb 12005 & 155 & 26.5 & 34.0 & 19.6 & 10.6 & 467.8 \\
\hline Feb 172005 & 171 & 23.9 & 30.5 & 17.0 & 2.9 & 355.5 \\
\hline
\end{tabular}

TABLE 3 - Correlation coefficients among biochemical and weather parameters for guava trees, fertigated with different doses of N and K. Petrolina-PE.

\begin{tabular}{|c|c|c|c|c|c|c|c|c|}
\hline & DAP & PP & AA & PROT & RS & SS & ST & SUC \\
\hline PP & $0.9649 * *$ & & & & & & & \\
\hline $\mathrm{AA}$ & $-0.3698 * *$ & $-0.3978 * *$ & & & & & & \\
\hline PROT & $0.8481 * *$ & $0.81804 * *$ & $-0.3603 * *$ & & & & & \\
\hline RS & $0.5188 * *$ & $0.52609 * *$ & $-0.3070 * *$ & $0.65005^{* *}$ & & & & \\
\hline AST & $0.4252 * *$ & $0.4616 * *$ & $0.02811^{\mathrm{ns}}$ & $0.47567 * *$ & $0.44267 * *$ & & & \\
\hline $\mathrm{ST}$ & $-0.1570^{\mathrm{ns}}$ & $-0.0503^{\mathrm{ns}}$ & $-0.00611^{\mathrm{ns}}$ & $-0.14992^{\mathrm{ns}}$ & $0.1021^{\mathrm{ns}}$ & $-0.02441^{\mathrm{ns}}$ & & \\
\hline SUC & $0.0683^{\mathrm{ns}}$ & $0.06821^{\mathrm{ns}}$ & $0.18721^{\mathrm{ns}}$ & $0.10675^{\mathrm{ns}}$ & $0.28093 * *$ & $0.47404 * *$ & $-0.00927^{\mathrm{ns}}$ & \\
\hline Tav & $-0.4352 * *$ & $-0.4469 * *$ & $0.31856^{* *}$ & $-0.4213 * *$ & $-0.16108^{\mathrm{ns}}$ & $0.27841 * *$ & $-0.06272^{\mathrm{ns}}$ & $0.33774 * *$ \\
\hline Tmax & $-0.2646 * *$ & $-0.2816 * *$ & $0.27425^{\mathrm{ns}}$ & $-0.2862 * *$ & $-0.0812^{\mathrm{ns}}$ & $0.38451 * *$ & $-0.07037^{\mathrm{ns}}$ & $0.39758 * *$ \\
\hline Tmin & $-0.7388 * *$ & $-0.7015 * *$ & $0.30848^{* *}$ & $-0.6409 * *$ & $-0.3041 * *$ & $-0.04463^{\mathrm{ns}}$ & $0.06569^{\text {ns }}$ & $0.01986^{\mathrm{ns}}$ \\
\hline INS & $-0.15712^{\mathrm{ns}}$ & $-0.1047^{\mathrm{ns}}$ & $0.24574^{\mathrm{ns}}$ & $-0.15986^{\mathrm{ns}}$ & $-0.01496^{\mathrm{ns}}$ & $0.54741 * *$ & $-0.01384^{\mathrm{ns}}$ & $0.4525 * *$ \\
\hline RAD & $-0.2738 * *$ & $-0.1956 * *$ & $0.32713 * *$ & $-0.1659^{\mathrm{ns}}$ & $-0.17969^{\mathrm{ns}}$ & $0.43052 * *$ & $-0.06784^{\mathrm{ns}}$ & $0.36907 * *$ \\
\hline
\end{tabular}

DAP- days after pruning; PP- phenological phase; AA- leaf amino acids content; PROT- leaf water-soluble proteins content; RS- leaf reducing sugars content; SS- leaf soluble sugars content; ST- leaf starch content; SUC- leaf sucrose content; Tav- average temperature; Tmax- maximum temperature; Tmin- minimum temperature; INS- insolation; RAD- global solar radiation; ** highly significant correlation $(\mathrm{P}<0,01)$; ${ }^{*}$ significant correlation $(\mathrm{P}<0,05)$; ${ }^{\text {ns }}$ non significant correlation $(\mathrm{P}>0,05)$. 


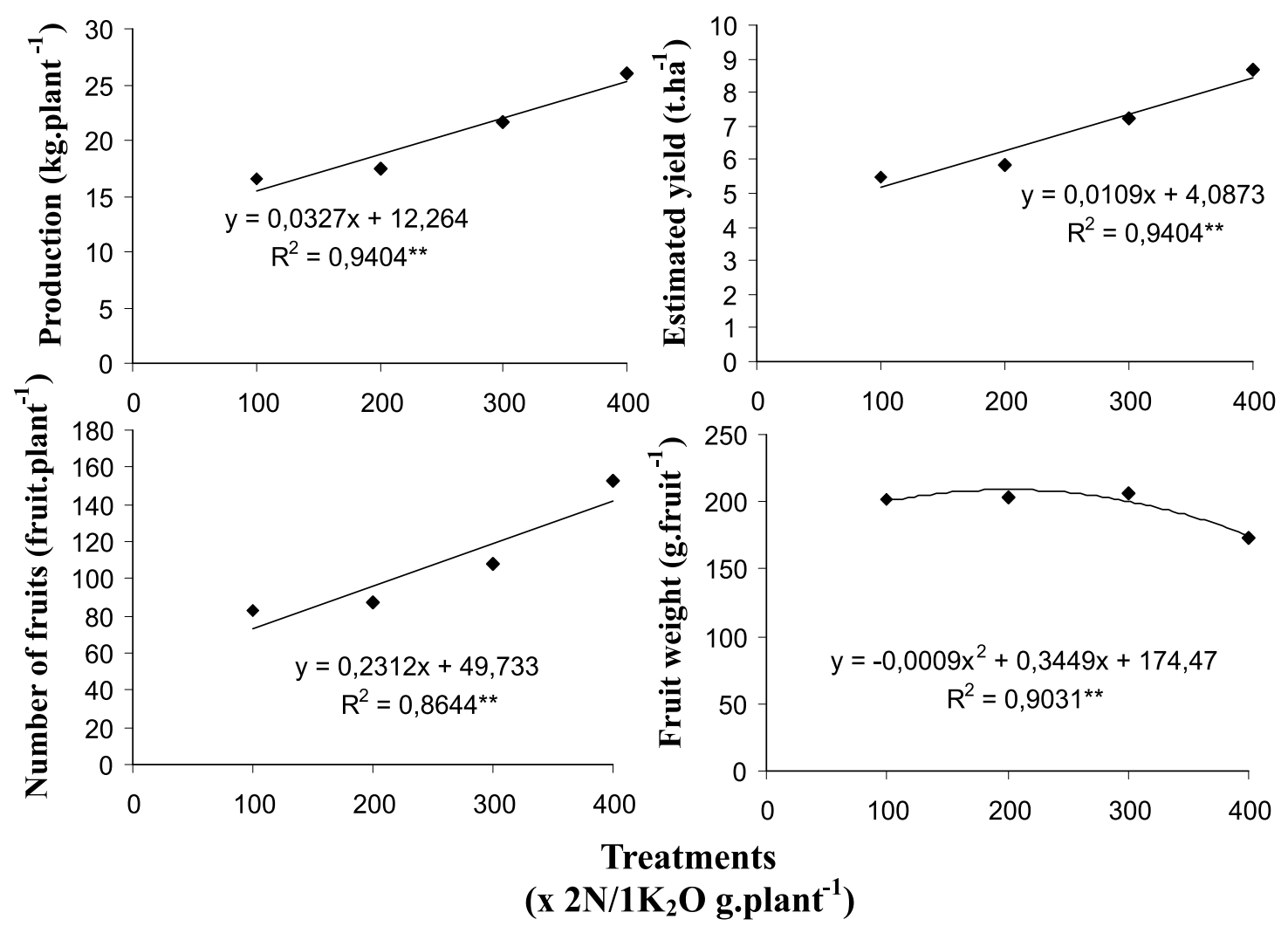

FIGURE 2 - Linear and polynomial regression for average production per plant (a), estimated yield (b), number of fruits (c) and fruits average weight (d) of guava trees, fertigated with different doses of $\mathrm{N}$ and $\mathrm{K}$. Petrolina-PE.

\section{CONCLUSION}

The doses of $\mathrm{N}$ and $\mathrm{K}$ induced higher yields of the guava trees, but in general didn't influence sugar and protein content in its leaves. These were only influenced by weather conditions and phenological phases.

\section{REFERENCES}

ALLEN, S.E.; GRIMSHAW, H.M.; PARKINSON, J.A.; QUARMBY, C. Chemical analyses of ecological materials. Oxford: Blackwell Scientific, 1977. 127p.

BITTENBENDER, H.C.; KOBAYASHI, K. Predicting the harvest of cycled 'Beaumont' guava. <http://www.ctahr.hawaii.edu/ kobayashik/guavaharv.html $>$ Acessado em 13/06/2005.

BRADFORD, M.M. A rapid and sensitive method for the quantitatification of microgram quantities of protein utilizing the principle of protein-dye binding. Analytical Biochemistry. San Diego, v.72, p.248-254, 1976.

COSTA, A. de F.S. da; COSTA, A.N. da. Tecnologias para a produção de goiaba. Vitória: Inscaper, 2003.341p.

FERREIRA, M.N.L. Distribuição radicular e consumo de água de goiabeira (Psidium guajava L.) irrigada por microaspersão em Petrolina-PE, 2004. 106p. Tese (Doutorado em Agronomia), Escola Superior de Agricultura
"Luiz de Queiroz", Universidade de São Paulo, Piracicaba, 2004.

HARTT, C.E. Effect of potassium deficiency of ${ }^{14} \mathrm{C}$ in attached blades and entire plants of sugarcane. Plant physiology. v.44, p.1461-1469. 1969.

KOCH, K.; \& MENGEL, K. Effect of K on N utilization by spring wheat during grain formation Agronomy Journal. v.69, p.477480.1977.

MALEK, F.; \& BAKER, D.A Proton co-transport of sugars in phloem loading. Planta. v.135, p.297-299. 1977

MENGEL, K.; \& KIRKBY, E.A. Principles of plant nutrition. Bern: International Potash Institute, 1987.687p.

MILLER, G.L. Use of dinitrosalicylis acid reagent for determination of reducing sugars. Analytical Chemistry, Washington, v..31, p.426-428, 1959.

MORIS, D.L. Quantitative determination of carbohydrates with Drywood's anthrone reagent. Science. Washington. v.107, p.254-255, 1948.

NATALE, W. diagnose Diagnose da nutriçao nitrogenada e potássica de duas cultivares da goiabeira (Psidium guajava L.) durante três anos. Piracicaba: Esalq, 1993. 149p. Tese (Doutorado em Agronomia), Escola Superior de Agricultura "Luiz de Queiroz", Univerdidade de São Paulo. Piracicaba, 1993.

PASSOS, L. P. Métodos analíticos e laboratoriais em fisiologia vegetal. Coronel Pacheco: Embrapa - CNPGL, 1996. 223p. 
PEOPLES T.R.; \& KOCH, D.W. Role of potassium on carbon dioxide assimilation in Medicago sativa L. Plant physiology. v.63, p.878-881. 1979.

PEREIRA, F.M. Cultura da Goiabeira. São Paulo: UNESP/FUNEP, 1995.30p.

PIMENTEL, C. Metabolsismo de carbono na agricultura tropical. Seropédica: Edur. 1998. 150p.

PIZA JUNIOR, C.; KAVATI, R. A cultura da goiaba de mesa. Campinas: CATI. 1994. 28p.

RATHORE, D.S. Effect of season in the growth and chemical composition of guava (Pisidium guajava L.). Journal of Horticultural Science, Ashford, v. 51, n.1, p.41-47, 1976.

ROSEN, H. A modified ninhydrin colorimetric analysis for amino acids. Archives of Biochemistry and Biophysics, San Diego, v.67, p.10-15, 1957.

SALVADOR, J.O.; MOREIRA, A.; MURAOKA, T. Deficiência nutricional em mudas de goiabeira decorrente da omissão simultânea de dois macronutrientes. Pesquisa Agropecuária Brasileira. Brasília, v.33, n.10, p.1623-1631. 1998.

SEÇER, M. Effect of potassium on nitrogen metabolization and grain protein formation in spring wheat. Kali-Brief. Buntehof, v.14, n.6, p.393-402. 1978.

SILVA, D.A.M.; VIEIRA, V.J.S.; MELO, J.J.L.; SILVAFILHO, A.V. Goiabeira (Psidium guayava): cultivo sob condicao irrigada. SEBRAE/CODEVASF, 1994. 31p. Recife:

TAIZ,L. \& ZEIGER, E. Plant physiology. New York: Benjamin Cummings, 1998.565p.

WALKER, R.R.; KRIEDEMANN, P.E.; MAGGS, D.H. Growth, leaf physiology and fruit development of salt stressed guavas. Australian Journal of Agricultural Research. v.30, p.477, 1979.

YEMM, E.W.; \& WILLIS, A.J. The estimation of carbohydrates in plants extracts by anthrone. Biochemical Journal. Colchester. v. 57, p.508-514, 1954. 